\title{
Erratum to: Induction of type I interferon by RNA viruses: cellular receptors and their substrates
}

\author{
Alina Baum • Adolfo García-Sastre
}

Published online: 17 February 2011

(C) Springer-Verlag 2011

Erratum to: Amino Acids (2010) 38:1283-1299

DOI 10.1007/s00726-009-0374-0

Unfortunately, there was an error in the acknowledgments section. The correct version is given below:

Acknowledgments Work in the laboratory of AG-S is being supported by NIH grants R01AI46954, P01AI58113, P01AI82325, U01AI70469, U19AI62623, U19AI83025, the Northeast Biodefense Center U54-AI057158-Lipkin and by CRIP (Center for Research in Influenza Pathogenesis), an NIAID funded Center of Excellence for Influenza Research and Surveillance, HHSN266200700010C.

The online version of the original article can be found under doi:10.1007/s00726-009-0374-0.

A. Baum · A. García-Sastre $(\bowtie)$ Department of Microbiology,

Mount Sinai School of Medicine,

1 Gustave L. Levy Place,

New York, NY 10029, USA

e-mail: adolfo.garcia-sastre@mssm.edu

\section{A. García-Sastre}

Department of Medicine,

Division of Infectious Diseases,

Mount Sinai School of Medicine,

1 Gustave L. Levy Place,

New York, NY 10029, USA

\section{A. García-Sastre}

Global Health and Emerging Pathogens Institute,

Mount Sinai School of Medicine,

1 Gustave L. Levy Place,

New York, NY 10029, USA 